\title{
Analysis of Land Uses In Iraqi Cities
}

\author{
Nabil T. Ismael ${ }^{1}$, Areej Muhy Abdulwahab ${ }^{2}$ \\ ${ }^{1}$ Department of Architecture, College of engineering, (MSc.), College of engineering, University of Diyala \\ E mail: nabiltaha2001@engineering.uodiyala.edu.iq, nabiltaha2001@gmail.com \\ ${ }^{2}$ Department of Highway and Transportation Engineering, College of engineering, University of Mustansiriyah \\ E mail: eng.areej.m@uomustansiriyah.edu.com, eng.areejmuhy1976@gmail.com
}

\begin{abstract}
Land use plans in Iraqi cities are traditional and don't seek to be sustainable and therefore could have negative impacts on the city from the environmental, economic, social and urban aspects. Consequently, the research aims to analyze the current and future of the land use for a set of Iraqi cities to reach the indicators of the gap between traditional and sustainable plans when planning for land uses.

The research conclusion is that most Iraqi cities are highly urban sprawl, both in reality and in the future expansion of the city. That is because it consumes a lot of agricultural land, cities with low population densities that are unsustainable, and most land uses are unsustainable focusing on reducing the agricultural and green lands in the city and increase residential uses (single type with very low density), and expand the areas of the streets that depend on the automated transportation more than sustainable transportation. The research suggests that sustainable land uses in Iraqi cities should be as follows:

- $\quad$ Residential use: vertical housing pattern $30 \%$, horizontal housing pattern $15 \%$.

- $\quad$ Mixed use $12 \%$.

- Green, open and recreational areas $22 \%$.

- Sustainable transport $13 \%$.

- $\quad$ Public, community and government services $8 \%$.
\end{abstract}

\section{INTRODUCTION}

Sustainability is concerned with the provision of a livable environment for human beings, and the sustainability of multiple strategies, including the sustainability of land uses in the city. This improves the built environment and spaces to make them integrated with each other.

The aim of providing a sustainable place for people with comfort and well-being, is through makeing land uses sustainable by increasing mixed uses, adopting sustainable transport and increasing green, water areas.

The research problem is that there is no sustainable future vision for land use in Iraqi cities when master plans are updated.

The research aims at developing sustainable land use rates used when preparing or updating the master plans, or when evaluating existing master plans.

The research methodology was based on Descriptive and Quantitative Analysis of the land uses of a set of Iraqi cities whose master plans were updated, in addition to the analysis of two phases the reality and the future vision of the land uses. This could provide a clear understanding about adopting the concept of sustainability in updating land uses in Iraqi cities.

\section{LAND USE AND SUSTAINABILITY}

During the past decades, the concept of sustainable development has established itself as a new requirement for urban and metropolitan level public action, which involves the design and practice of urban and land-use planning (Osaragi \& Nishimatsu, 2013, p. 31). 


\section{N. IS Wasit Journal \\ of Engineering Sciences}

VOLUME: ( 7 ), NO.: ( 3 ) 르미모

As more nations are implementing this concept in their development plans, it has created significant impacts on national policies and urban planning. The concern over sustainable urban development will continue to grow, especially in the developing countries which are undergoing rapid urbanization.

The conversion of agricultural land into urban land uses in the urbanization processes has become a earnest issue for sustainable urban development in the developing countries. This could be overcome through searching for better urban forms that can help to sustain development with focusing on the minimization of unnecessary agricultural land loss ( $\mathrm{Li}$ \& Yeh, 2000, p. 132).

In practice, land-use planning proved to be one of the most important areas in which conceptions of sustainable development are contested (Osaragi \& Nishimatsu, 2013, p. 32). However, in recent decades, the landscape of cities has changed significantly because of rapid urban population growth. A major feature of fast-growing cities is urban sprawl, which drives the occupation of large areas of land and is usually accompanied by many serious cases including inefficient land use, high car dependency, low density and high segregation of uses (UN-Habitat, 2014, p. 1).

Sustainable urban development requires policies to reduce energy consumption, reduce pollution and protect natural areas as well as agricultural land. The reuse of urban areas and more effective use of sites is a possible strategy that could be followed in both developing and developed countries.

The need for understanding land-use changes in order to improve land management, assess future trends and ensure environmental sustainability has given a rise to the novel discipline of land-use science (Marceau et al. 2013, p. 52).

Urban fringe dynamics place aa constrain on the open spaces that surround urban areas. This could limit the potential of these green areas for biodiversity, agricultural production and a wide range of other landscape services such as water regulation and storage, air quality improvement and recreational opportunities. Seeking a solution for the deterioration of these services has given rise to various forms of land-use policy that aim to steer urban fringe dynamics. Open space preservation policies in western countries generally aim to manage urban growth through a range of concepts such as zoning, urban growth boundaries, transfer of development rights and related financial instruments (Frenkel, 2004, p. $358)$.

Sustainable land use strategies have to respond to the following key issues (Halcrow, 2007, p. 210):

a) Urban sprawl, leapfrogging and poorly serviced development in peripheral areas.

b) Under-utilization of serviced vacant land and brownfield (derelict) sites.

c) Over requisitioning of land for projects/activities that may be unnecessary and inappropriate

d) Unacceptably long commuter journeys

Sustainable land uses require the following (Paola, 2006, pp. 12-16):

a) Consider the needs of the community.

b) Create viable and attractive developments.

c) Consider mixed-use developments.

d) Design to appropriately high densities.

e) Build on previously used and derelict land.

f) Protect local natural habitats.

g) Enhance the potential of land use for pedestrians and cyclists.

h) Include food production opportunities where it is possible.

i) Makes good public transport viable and, walking and cycling attractive options.

j) Encourages well-laid out urban areas with good quality buildings, well-designed streets, and good quality public open spaces.

k) Allows people to get to work easily and to the services they need like local shops, post offices, schools, health and leisure facilities.

\section{SUSTAINABILITY CRITERIA FOR LAND USE}

UN-Habitat supports countries to develop urban planning methods and systems to address current urbanization challenges such as population growth, urban sprawl, poverty, inequality, pollution, congestion, urban biodiversity, urban mobility and energy, through five criteria (UN-Habitat, 2014, p. 1):

a) Adequate space for streets and an efficient street network: The street network should occupy at least 30 per cent of the land and at least $18 \mathrm{~km}$ of street length per $\mathrm{km}^{2}$. 


\section{V/JIS Wasit Journal}

VOLUME: ( 7 ), NO.: ( 3 ) 르미므

b) High density: At least 15,000 people per $\mathrm{km}^{2}$, that is 150 people/ha or 61 people/acre.

c) Mixed land-use: At least $40 \%$ of floor space should be allocated for economic use in any neighborhood.

d) Social mix: The availability of houses in different price ranges and tenures in any given neighborhood to accommodate different incomes; 20 to 50 per cent of the residential floor area should be for low cost housing; and each tenure type should be not more than 50 per cent of the total.

e) Limited land-use specialization. This is to limit single function blocks or neighborhoods; single function blocks should cover less than 10 per cent of any neighborhood. The unilateral application of land-use specialization creates many single-function neighborhoods. That is the source of contemporary urban challenges including city congestion, segregation, car dependency, etc. Limiting land use specialization is important to create mixed landuse. There are two ways to adjust zoning policies and apply (UN-Habitat, 2014, p. 7):

- to combine compatible land-uses into one block and neighborhood;

- to introduce mixed land-use zoning while respecting market demand and cities' urban by-laws and regulations.

Land use ratios for sustainable Masdar City were as follows (Wagle, 2014, p. 8):

a) Residential use $62 \%$.

b) Commercial use $13 \%+$ Retail $2 \%$.

c) Community facilities $12 \%$.

d) Light industries $11 \%$.

\section{THE EXISTING AND FUTURE OF LAND USES FOR THE IRAQI CITIES}

The cities were selected according to their potentials available in the city, for example:

- The cities of Basra and Amarah are characterized by their economic potentials such as oil and border crossings.

- The cities of Ramadi and Hillah have a high level of human potential.

- The city of Al Muqdadiya and Balad that they possess enormous agricultural potential with the characteristics of the green city.

- The city of Karbala is one of the most important Islamic holy cities with the characteristics of religious tourism.

\section{1) Basra City}

It is the center of Basra governorate, the third largest governorate in Iraq, located in southern Iraq, surrounded by countries of Kuwait, Iran and Saudi Arabia. It has a significant economic potential, including oil resources, seaports, border crossings and other resources (Fig. 1).

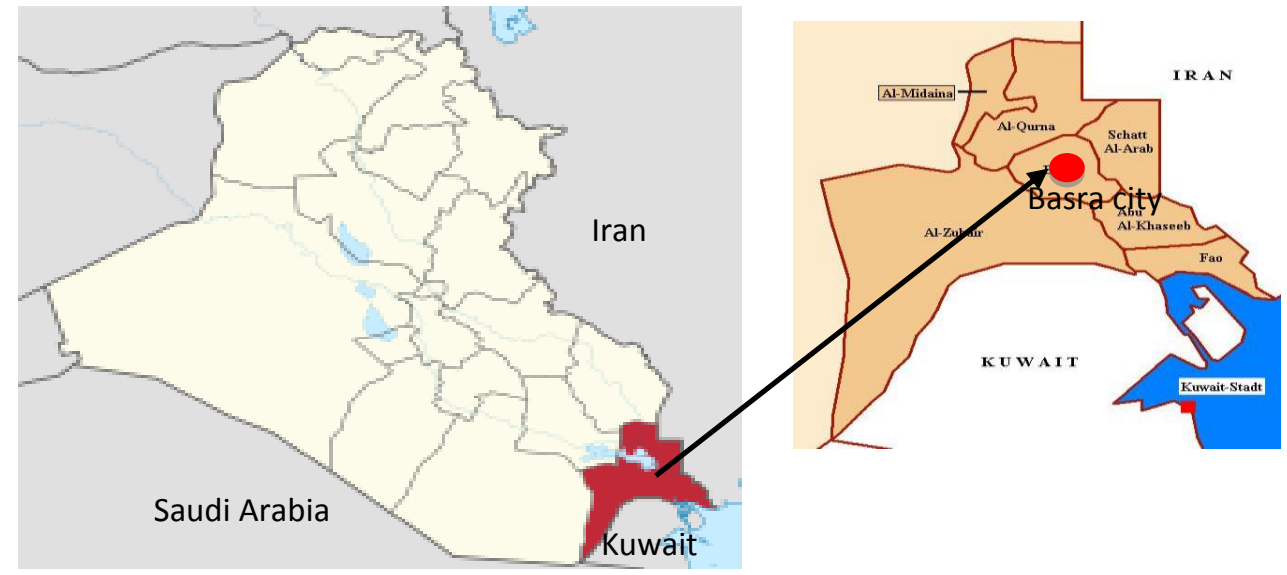

Fig.1. The location Basra governorate and Basra city in Iraq 
Table (1) shows the following:

- The annual growth rate of the population and the area shows an excessive increase in the annual growth of the city area of $4.64 \%$ per annum compared with the annual population growth of $2.86 \%$. This growth is unsustainable for land use.

- The city is characterized by a low density from 67 people/ha to 47 people/ha in 2030, which is an unsustainable indicator of the city's trend towards increasing urban sprawl rather than compact and proximity in the fabric of city, as well as increasing the area per person from $149 \mathrm{~m}^{2}$ to $214 \mathrm{~m}^{2}$ per in 2030.

- The plan 2030 of the city of Basra has been adopted to increase some rates of land use and others to reduce it, as follows:

- Increase the percentage of residential use from $24.76 \%$ in 2009 to $34.28 \%$ in 2030 , to accommodate the increased population growth and solve the housing problem.

- An excessive increase in the transportation use from $2.29 \%$ in 2009 to $21 \%$ in 2030 to meet the economic development, especially the existing and future industrial. However, this increase is focused on the construction of highways and has not focused on providing a sustainable transport infrastructure such as walking and biking.

- Increasing the percentage of industrial use from 3.52\% in 2009 to $9.8 \%$ in 2030 as a result of the development in the oil sector and the possibility of establishing additional heavy industries in the future. However, it is a factor to increase pollution in the city.

- The percentage of commercial and mixed use increased from $1.19 \%$ in 2009 to $2.8 \%$ in 2030, which increases the city's commercial activity and increases the future employment opportunities of the city as a result of the increase in household income and the expected economic growth of the city.

- Increase the percentage of community services from $0.1 \%$ to $4.2 \%$ in 2030 , to accommodate all future social needs from service and religious facilities.

- A slight increase in the use of health and education, as health use increased from $0.43 \%$ to $2.2 \%$, and educational use increased from 1.94 to $2.9 \%$ in 2030. This is a positive indicator of the increasing percentage of educational and health uses that are directly related to improving education, culture and community health.

- The percentage of recreational uses, green and open spaces decreased from $15.89 \%$ in 2009 to $11.5 \%$ in 2030 . This is an unsustainable indicator that works to reduce the level of well-being, environmental degradation and reduces the appropriate and adequate recreational areas for the population.

- The decline in the use of public and civil services from 7.17\% in 2009 to $3.4 \%$ in 2030, which is a negative indicator in reducing the percentage of areas allocated for providing services to the population and distributing them in an equal and harmonious manner in the city.

The future land use plan in Basra city is unsustainable by focusing on increasing the land use that pollutes the environment and reducing land uses that improve the environment and provide a healthy and suitable environment for people. In addition, it increases the excessive annual spatial expansion in the consumption of agricultural land and open space in the city.

- $\quad$ TABle 1. Land USe OF BASRA City FOR 2009 AND 2030.

\begin{tabular}{|c|c|c|c|c|c|c|}
\hline \multirow{2}{*}{ Land Use } & \multicolumn{3}{|c|}{2009} & \multicolumn{3}{|c|}{2030} \\
\hline & Area (ha) & \multicolumn{2}{|c|}{ Percentage } & Area (ha) & \multicolumn{2}{|c|}{ Percentage } \\
\hline Residential & 4435 & \multicolumn{2}{|c|}{$24.76 \%$} & 15917 & \multicolumn{2}{|c|}{$34.28 \%$} \\
\hline Commercial/Mixed & 213 & \multicolumn{2}{|c|}{$1.19 \%$} & 1314 & \multicolumn{2}{|c|}{$2.8 \%$} \\
\hline Industrial & 630 & \multicolumn{2}{|c|}{$3.52 \%$} & 4548 & \multicolumn{2}{|c|}{$9.8 \%$} \\
\hline Educational & 347 & \multicolumn{2}{|c|}{$1.94 \%$} & 1345 & \multicolumn{2}{|c|}{$2.9 \%$} \\
\hline Public and civil services & 1285 & \multicolumn{2}{|c|}{$7.17 \%$} & 1563 & \multicolumn{2}{|c|}{$3.4 \%$} \\
\hline Healthy & 77 & \multicolumn{2}{|c|}{$0.43 \%$} & 1005 & \multicolumn{2}{|c|}{$2.2 \%$} \\
\hline Community services (religious and social facilities) & 18 & \multicolumn{2}{|c|}{$0.1 \%$} & 1965 & \multicolumn{2}{|c|}{$4.2 \%$} \\
\hline $\begin{array}{l}\text { Cultural and recreational (heritage, sports, recreational } \\
\text { facilities) }\end{array}$ & 510 & $2.84 \%$ & \multirow{2}{*}{$15.89 \%$} & 601 & $1.3 \%$ & \multirow{2}{*}{$11.5 \%$} \\
\hline $\begin{array}{c}\text { Open space and agricultural land (agricultural, } \\
\text { orchards, public open spaces) }\end{array}$ & 2339 & $13.05 \%$ & & 4714 & $10.2 \%$ & \\
\hline $\begin{array}{l}\text { Transportation (infrastructure, shipping, airport, } \\
\text { railway, parking) }\end{array}$ & 413 & \multicolumn{2}{|c|}{$2.29 \%$} & 9749 & \multicolumn{2}{|c|}{$21 \%$} \\
\hline
\end{tabular}




\section{VNJIS Wasit Journal}

VOLUME: ( 7 ), NO.: ( 3 ) 르밈

\begin{tabular}{|c|c|c|c|}
\hline $\begin{array}{c}\text { Other uses (cemeteries, military, channels and land } \\
\text { that can't be developed) }\end{array}$ & 522 & $2.92 \%$ & 3709 \\
\hline Land designated for future development & 7124 & $39.77 \%$ & 0 \\
\hline Total land use (ha) & $\mathbf{1 7 9 1 3}$ & $\mathbf{4 6 4 3 0}$ & $\mathbf{2 1 7 1 0 0 0}$ \\
\hline Population (person) & $\mathbf{1 2 0 0 0 0 0}$ & $\mathbf{4 7}$ \\
\hline Density (person / ha) & $\mathbf{6 7}$ & $\mathbf{2 1 4}$ \\
\hline per capita area (m) & $\mathbf{1 4 9}$ & $\mathbf{2 . 8 6} \%$ \\
\hline Annual population growth & & $\mathbf{4 . 6 4 \%}$ \\
\hline
\end{tabular}

Ministry of Municipalities and Public Works, General Directorate of Physical Planning (2012) "Basra City Development Strategy and Update the Master Plan" Report of the sixth phase, chapter III, p. 8, chapter IV p. 1, and chapter VI p. 1.

\section{2) Amarah City}

It is center of Maysan Governorate, located in the southeast of Iraq, bordered to the east by Iran (Fig. 2), a tribal city with a set of marshes, oil sites and border crossings with Iran, which are of an agricultural environment.

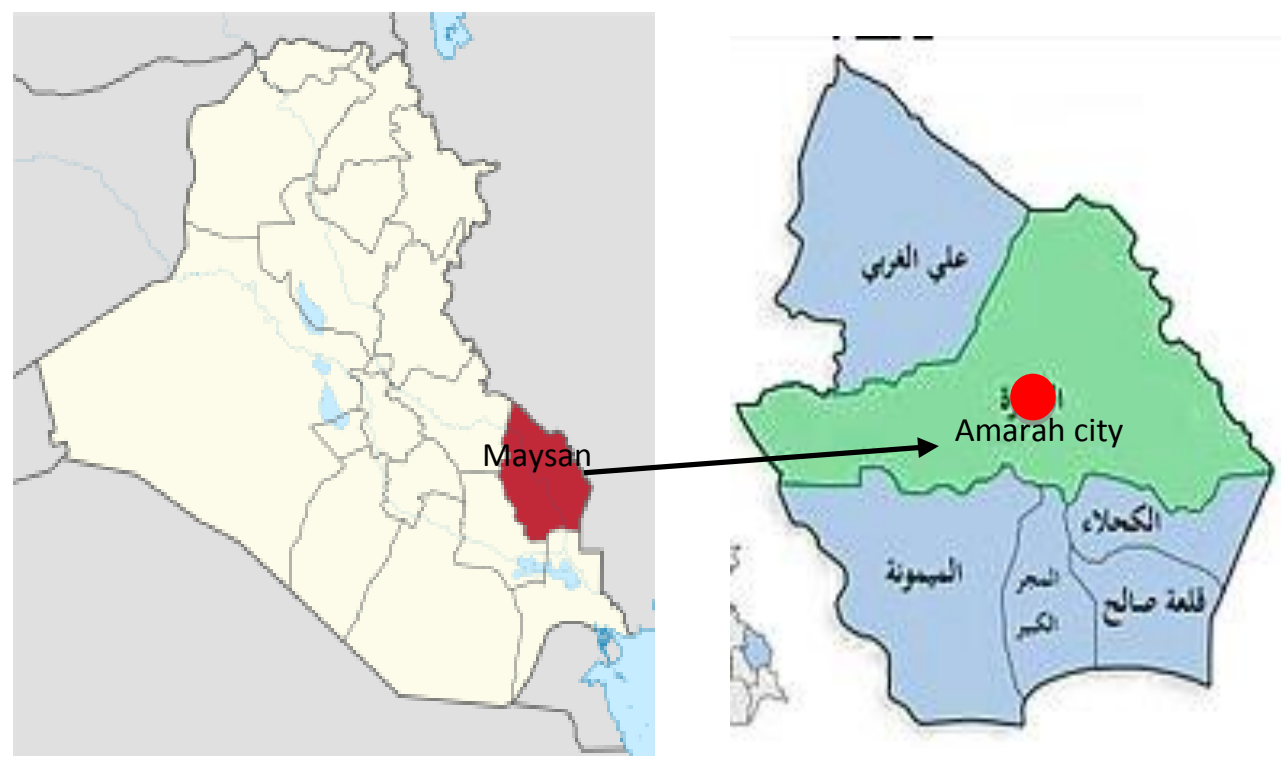

Fig. 2. Location of Maysan governorate and Amara city in Iraq

Table (2) shows the following:

- The population growth rate of the city is $2.3 \%$, which is acceptable with the national average of Iraq. However, the annual growth rate of the area of $4.18 \%$ is high and doesn't correspond to the population growth. This could be considered as an unsustainable indicator based on the city's urban sprawl and the random expansion.

- The city is characterized by a low density from 112 people/ha to 74 people/ha in 2030, which is an unsustainable indicator of the city's tendency to increase urban sprawl rather than compact and proximity in the city.

- The plan (2030) of Amara city focused on increasing the per capita share of the city land from $89 \mathrm{~m}^{2}$ per person to $135 \mathrm{~m}^{2}$ in 2030, to achieve well-being and improve the standard of living. However, this area is unsustainable.

- The reduction of land use of residential, road and transportation networks by $16 \%$, and other uses (educational, commercial, governmental and security, mixed use) by about $3 \%$. In contrast, this percentage increased for the land use of open space and recreational areas, sports and youth, culture and tourism by about $15 \%$. An increased 
industrial use and public and health facilities also increased by about $4 \%$. This is a positive indicator of the increased green area and open space in the city.

- The plan focused on increasing the city's open space, recreational and cultural areas in 2030. The percentage of these land uses was $1.73 \%$ in 2007, while the plan aims to reach $16.47 \%$ in 2030, as a result of the shortage of these land uses in the city today. Therefore, it is noted that the urban sprawl of the city focuses on increasing the open space and reducing the built-up to achieve a balance between them.

The land use plan 2030 in Amara city was special the balance between built-up and open space, as the city was characterized by competence and proximity activities, and a lack of open space and green areas. This requires increasing the percentages of these land uses and achieve a balance between the built-up and open space.

TABLE 2. LAND USE OF AMARA CITY FOR 2007 AND 2030.

\begin{tabular}{|c|c|c|c|c|}
\hline \multirow{2}{*}{ Land Use } & \multicolumn{2}{|c|}{2007} & \multicolumn{2}{|c|}{2030} \\
\hline & Area (ha) & Percentage & Area (ha) & Percentage \\
\hline Residential & 1808.73 & $56.30 \%$ & 3883.33 & $47.15 \%$ \\
\hline Mixed use & 4.01 & $0.12 \%$ & 4.01 & $0.05 \%$ \\
\hline Commercial and Institutional & 55.85 & $1.74 \%$ & 134 & $1.63 \%$ \\
\hline Industrial and Warehouses & 189.39 & $5.90 \%$ & 719.85 & $8.74 \%$ \\
\hline Education & 143.05 & $4.45 \%$ & 212.93 & $2.59 \%$ \\
\hline Health & 14.53 & $0.45 \%$ & 69.09 & $0.84 \%$ \\
\hline Administration and security & 41.57 & $1.29 \%$ & 51.87 & $0.63 \%$ \\
\hline Religious & 6.6 & $0.21 \%$ & 20.2 & $0.25 \%$ \\
\hline Cultural and tourism & 3.14 & $0.10 \%$ & 389.01 & $4.72 \%$ \\
\hline Open space/recreation/sports/youth/cemeteries & 52.39 & $1.63 \%$ & 967.83 & $11.75 \%$ \\
\hline Transportation and road network & 800.78 & $24.93 \%$ & 1492.32 & $18.12 \%$ \\
\hline Public services & 92.59 & $2.88 \%$ & 292.34 & $3.55 \%$ \\
\hline Total land use (ha) & 3212.63 & & 8236.78 & \\
\hline Population (person) & 360800 & & 608574 & \\
\hline Density (person / ha) & 112 & & 74 & \\
\hline per capita area $\left(\mathbf{m}^{2}\right)$ & 89 & & 135 & \\
\hline Annual population growth & & $2.3 \%$ & & \\
\hline Annual area growth & & $4.18 \%$ & & \\
\hline
\end{tabular}

Ministry of Municipalities and Public Works, General Directorate of Physical Planning (2009) "Amara Master Plan Update" Population and demographic characteristics Report, p. 3-7, 3-23 and 12-40.

\section{3) Ramadi City}

It is the center of Al Anbar governorate located in western Iraq and west of Baghdad governorate (Fig. 3), located on the international road linking Syria and Jordan. It is a city of tribal, desert environment, and includes various development potential including natural resources such as phosphate, lime and others, as well as the presence of international roads main and border crossings with Jordan and Syria.

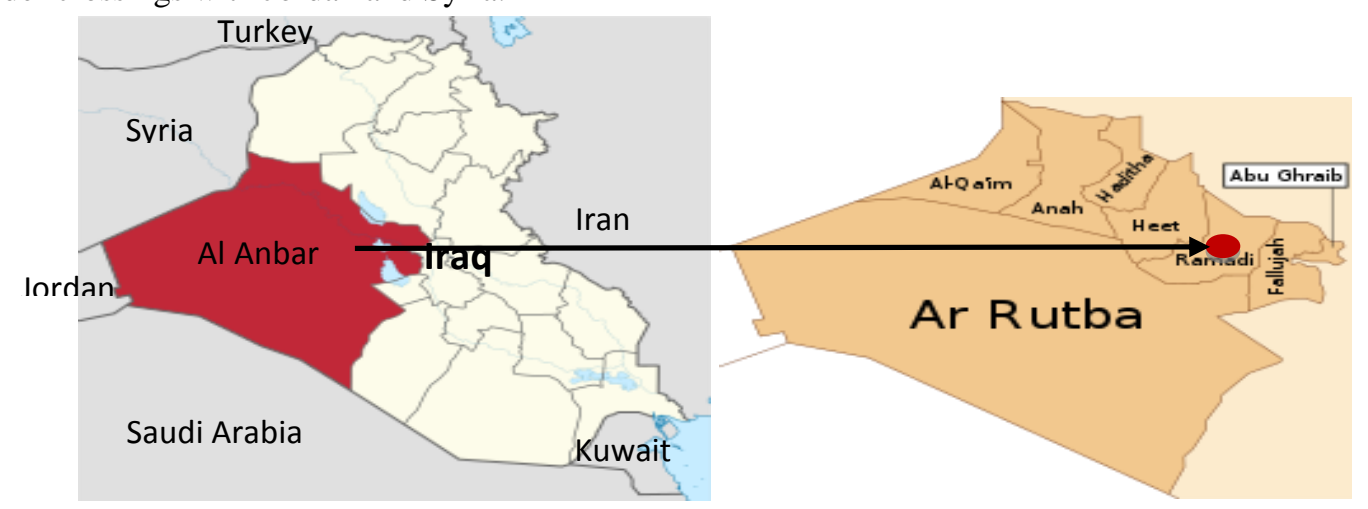

Fig. 3. Location of Al Anbar governorate and Ramadi city in Iraq 
Table (3) shows the following:

- The population density in 2009 (62 persons/ha) and the projected density in 2033 (71 persons/ha) are low and unsustainable compared to the United Nations standards (150 persons/ha).

- The highest land use in Ramadi city is residential use $30.8 \%$, followed by green areas by $17.8 \%$, followed by the roads and transportation network by $11.6 \%$ in 2009 . While it is noted that in 2033 , the increase in the percentage of residential use has to reach $36.5 \%$.

The percentage is low with a sustainable ratio of $62 \%$ in Masdar city to provide a livable living environment, followed by an increase in the percentage of transportation network to $19.3 \%$. This increase encourages to use of private cars, especially since it does notinclude support for sustainable transport in the city. While the percentage of green areas decreased to $13.1 \%$, which is contrary to the principles of sustainability.

- Industrial use: the percentage of industrial use decreased from $5.9 \%$ in 2009 to $4.3 \%$ in 2033, due to the decline of the industrail sector in Iraq and the attempt to reduce the negative environmental impacts of industry on the city.

- Commercial use: the percentage of commercial use decreased from $1.4 \%$ to $1.2 \%$ in 2033, as well as the attempt to add mixed uses as a support for sustainability in cities, as it was added to commercial use not separately.

- Educational and health use: the percentage of educational use decreased from $7.1 \%$ to $3.8 \%$ in 2033 , while the percentage of health use increased from $0.6 \%$ to $0.9 \%$. Those uses need to be highly developed because they are directly linked to the development of society and the increasing level of education, culture and health of residents and the improving of the life quality.

- Recreation and water areas increased from $3 \%$ in 2009 to $3.7 \%$ in 2033 . This is a positive indicator of the city as a desert city and needs to reduce the high temperatures. Recreational areas kept the same percentage of $2.5 \%$, which is low for the city.

- Buildings and public services decreased from $5.2 \%$ in 2009 to $2.2 \%$ in 2033; this is a negative indicator of the low distribution and concentration of services in the city.

- Other land uses: not more than $13 \%$, a set of land uses related to transport and investment and a hierarchy of service centers in the city.

- The decrease of the per capita area in the city from $162 \mathrm{~m}^{2}$ to $140 \mathrm{~m}^{2}$. This reduces the level of well-being of the per capita, especially in Ramadi city, which is characterized by tribal character and desire of the population to own large houses. However, this indicator per capita is unsustainable and a high area compared to per capita area in Masdar city $\left(78 \mathrm{~m}^{2}\right)$.

- The land uses for Ramadi city has been concentrated 2033 on the increase in residential use (30.8\% to 36.5\%) and economic and transportation use (27.4\% to $31.1 \%)$. In contrast, reduce the percentage of public service uses (16.9\% to $13.1 \%)$ and green and blue (water) areas (23.3\% to $19.3 \%)$.

The approach adopted to update the master plan and land use of Ramadi city is a traditional approach that doesn't depend on sustainability, especially that location of the desert for Ramadi city needs more compactness and proximity between activates with increased water and green areas to provide a favorable environment for the community.

TABLE 3. LAND USE OF RAMADI CITY FOR 2009 AND 2033

\begin{tabular}{|c|c|c|c|c|}
\hline \multirow{2}{*}{ Land Use } & \multicolumn{2}{|c|}{$\mathbf{2 0 0 9}$} & \multicolumn{2}{c|}{$\mathbf{2 0 3 3}$} \\
\cline { 2 - 4 } & Area (ha) & Percentage & Area (ha) & Percentage \\
\hline Residential & 1773 & $30.8 \%$ & 4306 & $36.5 \%$ \\
\hline Industrial & 338 & $5.9 \%$ & 510 & $4.3 \%$ \\
\hline Commercial and Mix use & 78 & $1.4 \%$ & 147 & $1.2 \%$ \\
\hline Education & 410 & $7.1 \%$ & 454 & $3.8 \%$ \\
\hline Religious & 21 & $0.4 \%$ & 23 & $0.2 \%$ \\
\hline Health & 33 & $0.6 \%$ & 102 & $0.9 \%$ \\
\hline Public Buildings and services & 298 & $5.2 \%$ & 264 & $2.2 \%$ \\
\hline Recreation & 146 & $2.5 \%$ & 300 & $2.5 \%$ \\
\hline Green areas & 1024 & $17.8 \%$ & 1549 & $13.1 \%$ \\
\hline Train station and railway & 405 & $7 \%$ & 385 & $3.3 \%$ \\
\hline
\end{tabular}




\section{N. Wasit Journal}

VOLUME: ( 7 ), NO.: ( 3 ) 르모

\begin{tabular}{|c|c|c|c|c|}
\hline Water area & 172 & $3 \%$ & 438 & $3.7 \%$ \\
\hline Cemeteries & 207 & $3.6 \%$ & 110 & $0.9 \%$ \\
\hline Transportation and roads network & 670 & $11.6 \%$ & 2276 & $19.3 \%$ \\
\hline Warehouse and oil stores & 89 & $1.5 \%$ & & \\
\hline Military area & 79 & $1.4 \%$ & & \\
\hline Special area & 21 & $0.4 \%$ & & \\
\hline Administrative and residential centers & & & 591 & $5.1 \%$ \\
\hline Cultural areas & & & 3 & $0.03 \%$ \\
\hline Tourist investment & & & 304 & $2.6 \%$ \\
\hline Car Showrooms & & & 17 & $0.1 \%$ \\
\hline International transportation garage & & & 30 & $0.3 \%$ \\
\hline Total land use (ha) & 5764 & & 11809 & \\
\hline Population (person) & 355909 & & 841100 & \\
\hline Density (person / ha) & 62 & & 71 & \\
\hline per capita area $\left(\mathrm{m}^{2}\right)$ & 162 & & 140 & \\
\hline Annual population growth & \multicolumn{3}{|c|}{$3.65 \%$} & \\
\hline Annual area growth & \multicolumn{3}{|c|}{$3.03 \%$} & \\
\hline
\end{tabular}

Ministry of Municipalities and Public Works, General Directorate of Physical Planning (2012) "Ramadi City

Development Strategy and Update the Master Plan" Report of Phase V, Final Outline of the Master Plan, pp. 25, 26 and 172 .

\section{4) Hillah City}

It is the center of Babylon governorate, located in central of Iraq, south of Baghdad, surrounded by a group of governorates (Karbala, Najaf, Diwaniyah, Wasit, Baghdad) (Figure 4).

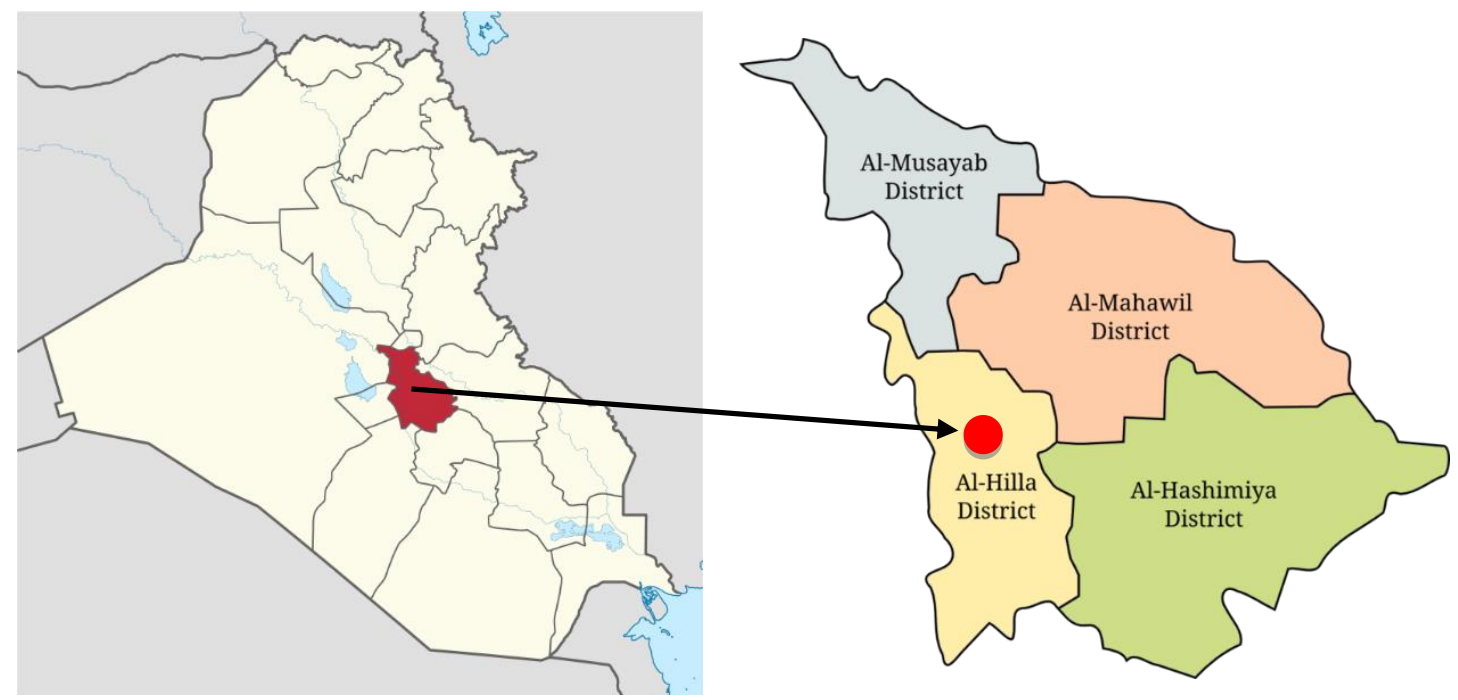

Fig. 4. Location of Babylon governorate and Hillah city in Iraq

Table (4) shows the following:

- The annual growth rate of the population is $2.51 \%$, and the annual growth of the area is $4.26 \%$, which is an indicator of the urban sprawl of the city by a large percentage.

Which affected the low density from 89 people / ha in 2006 to 59 people / ha in 2030, as well as increasing the per capita area in the city from $112 \mathrm{~m}^{2}$ in 2006 to $169 \mathrm{~m}^{2}$ in 2030, which is an unsustainable indicator of the city.

- Land use in the city decreased by $13.43 \%$ in 2030 from existing (2006), as residential use decreased by $4.55 \%$, educational use by $3.11 \%$, administrative and security use of $1.83 \%$, commercial use by $1.68 \%$, and other land 


\section{VNJIS Wasit Journal}

VOLUME: ( 7 ), NO.: ( 3 ) 르미므

uses (mixed, Industrial, health, religious, infrastructure) by $2.26 \%$. This indicates that there are sufficient land uses for the city's existing in 2006 according to the standards.

- $\quad$ The percentage of open areas, sports, youth and recreation increased from $1.98 \%$ in 2006 to $10.4 \%$ in 2030 . The increase in the percentage of cultural tourism use increased from $0.2 \%$ in 2006 to $2.53 \%$ in 2030, which indicates the apparent lack of recreational and recreational uses in the city in the year 2006 . They need to be increased to meet the standards and requirements of the community.

The land use plan focused on increasing the city's open space and recreational areas to meet the needs of the future population to provide a suitable and sustainable environment. However, this expansion has been the result of urban sprawl and the exhaustion of the city's surrounding land. This represents an unsustainable indicator of the expansion of land uses.

TABLE 4. LAND USE OF HILlAH CITY FOR 2006 AND 2030.

\begin{tabular}{|c|c|c|c|c|}
\hline \multirow[b]{2}{*}{ Land Use } & \multicolumn{2}{|c|}{2006} & \multicolumn{2}{|c|}{2030} \\
\hline & Area (ha) & Percentage & Area (ha) & Percentage \\
\hline Residential & 1724.6 & $51.27 \%$ & 4275.6 & $46.72 \%$ \\
\hline Mix use & 70.4 & $2.09 \%$ & 110.5 & $1.21 \%$ \\
\hline Commercial & 135.1 & $4.02 \%$ & 214.4 & $2.34 \%$ \\
\hline Industrial & 217.3 & $6.46 \%$ & 532.9 & $5.82 \%$ \\
\hline Education & 204.9 & $6.09 \%$ & 272.9 & $2.98 \%$ \\
\hline Health & 30.8 & $0.92 \%$ & 83.8 & $0.92 \%$ \\
\hline Cultural / tourism & 4.2 & $0.12 \%$ & 231.3 & $2.53 \%$ \\
\hline $\begin{array}{c}\text { Open Spaces / Sports / Youth / } \\
\text { Recreation }\end{array}$ & 66.6 & $1.98 \%$ & 1123.5 & $12.28 \%$ \\
\hline Religious & 12.3 & $0.37 \%$ & 29.3 & $0.32 \%$ \\
\hline Administrative and security & 106.8 & $3.17 \%$ & 122.9 & $1.34 \%$ \\
\hline Infrastructure & 111 & $3.3 \%$ & 237.5 & $2.6 \%$ \\
\hline Transportation & 680 & $20.21 \%$ & 1916.7 & $20.94 \%$ \\
\hline Total land use (ha) & 3364 & & 9151.3 & \\
\hline Population (person) & 299560 & & 542630 & \\
\hline Density (person / ha) & 89 & & 59 & \\
\hline per capita area $\left(\mathbf{m}^{2}\right)$ & 112 & & 169 & \\
\hline Annual population growth & & $2.51 \%$ & & \\
\hline Annual area growth & & $4.26 \%$ & & \\
\hline
\end{tabular}

Ministry of Municipalities and Public Works, General Directorate of Physical Planning (2009) "Hillah Master Plan Update” Report of Phase VI, Chapter III, pp. 8 and 49.

\section{5) Al Muqdadiya City}

It is the second largest district in Diyala governorate, located in eastern Iraq, is a fertile agricultural area include large agricultural areas and orchards, located on an international road linking Iraq to Iran (Fig. 5).

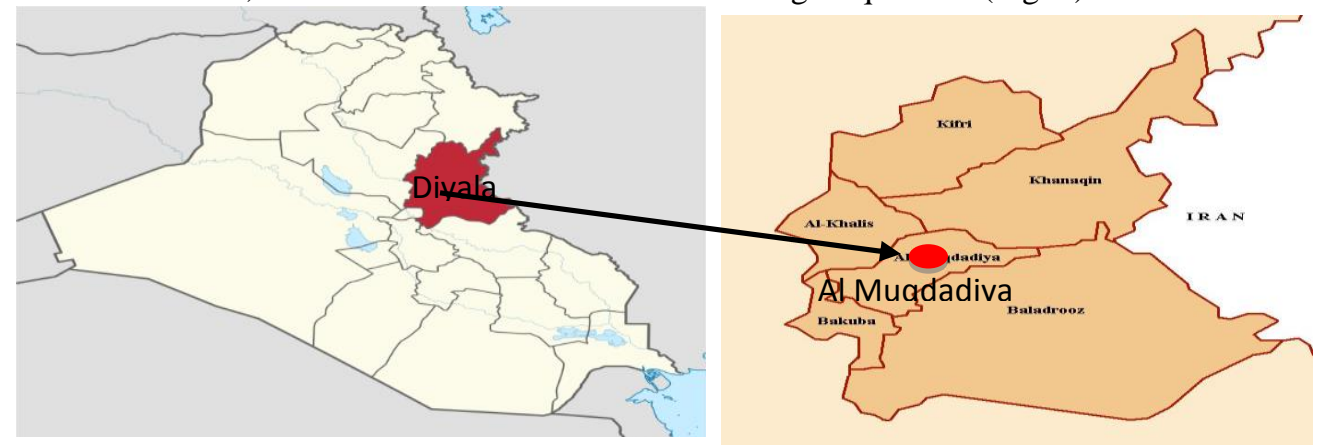

Fig. 5. Location of Diyala governorate and Al Muqdadiya city in Iraq 
Table (5) shows the following:

- Annual population growth rate (3.47\%) greater than the annual growth of area (2.07\%). This is an indicator of an increase in population density (from 35 to 46 people/ha), as well as a reduction in the city's per capita area from 284 $\mathrm{m}^{2}$ to $216 \mathrm{~m}^{2}$. However, this area and density is unsustainable and leads to large consumption of arable land.

- Land use decreased by about $23 \%$ in Al Muqdadiya city, as follows:

- The decrease in residential use by $14.5 \%$ in 2030 as a result of a large surplus currently unused as housing and lack of infrastructure services for this use.

- The decline of agricultural areas by $8.21 \%$ and its conversion to other land uses, this is a negative indicator of the city, especially as the city is characterized by the nature of green, which includes more areas of orchards and water resources.

- Land use increased by $19.56 \%$ in Al Muqdadiya city, as follows:

- The city's open space and green areas increased by $5.7 \%$; this is a positive indicator in providing green and recreational areas for the city's residents.

- Increase in road and transportation use by $3.6 \%$ from the existing, to meet the city's future urban expansion with the increase in industrial and commercial uses of the city, up to $25.6 \%$, which is a high percentage that encourages the use of the private car.

- Industrial use increased by $2.92 \%$ because of the large economic potential and natural resources in the city, which encourages increased industrial activity in the city. However, it increased the pollution rate in the city, especially that most of the industries are environmentally polluted.

- Increase in educational use by $2.6 \%$, due to the apparent lack of education and the attempt to reduce the gap between the existing and the future.

- The city's administrative use has increased by $1.38 \%$, to meet future requirements, increase the city's administrative activities and improve the services provided to the population, a positive indicator of the city.

- Commercial use increased by $1.15 \%$ to expect the city to be an international trade center linking Iraq with Iran and other countries, this is a positive indicator of the city.

- The increase in health, religious, cultural and sporting uses in a small percentage to a total of $1.83 \%$ of the existing. This percentage is very low because of the importance of those uses in the city, which is working to improve the health and cultural level of community.

Although Al Muqdadiya city is a green city that includes many orchards and agricultural areas within the city, the future expansion has led to the exhaustion of green areas and the encouragement of the increased use of private cars. This have environmental and health effects on the population.

TABLE 5. LAND USE OF AL MUQDADIYA CITY FOR 2010 AND 2030

\begin{tabular}{|c|c|c|c|c|}
\hline \multirow{2}{*}{ Land Use } & \multicolumn{2}{|c|}{ 2010 } & \multicolumn{2}{c|}{ 2030 } \\
\cline { 2 - 5 } & Area (ha) & Percentage & Area (ha) & Percentage \\
\hline Residential & 899.36 & $40.7 \%$ & 883.62 & $26.2 \%$ \\
\hline Commercial & 34.15 & $1.55 \%$ & 89.15 & 2.7 \\
\hline Industrial & 41.48 & $1.88 \%$ & 159 & $4.8 \%$ \\
\hline Educational & 53.07 & $2.4 \%$ & 167.36 & $5 \%$ \\
\hline $\begin{array}{c}\text { Government } \\
\text { administration and public } \\
\text { services }\end{array}$ & 2.65 & $0.12 \%$ & 50.13 & $1.5 \%$ \\
\hline Infrastructures & 2.79 & $0.13 \%$ & & \\
\hline Health & 4.7 & $0.21 \%$ & 28.3 & $0.9 \%$ \\
\hline Religious & 10.47 & $0.47 \%$ & 28.19 & $0.8 \%$ \\
\hline Tourism and Recreation & 11.09 & $0.5 \%$ & 13.39 & $0.4 \%$ \\
\hline Cultural & 0.44 & $0.02 \%$ & 12.29 & $0.4 \%$ \\
\hline heritage & 0.5 & $0.02 \%$ & & \\
\hline Sports and Youth & 8.26 & $0.37 \%$ & 43.49 & $1.3 \%$ \\
\hline Security & 4.91 & $0.22 \%$ & & \\
\hline Transportation & 486.22 & $22 \%$ & 851.88 & $25.6 \%$ \\
\hline Open space and green & 37.57 & $1.7 \%$ & 244.82 & $7.4 \%$ \\
\hline
\end{tabular}




\section{N.J Wasit Journal}

\begin{tabular}{|c|c|c|c|c|}
\hline areas & & & & \\
\hline Agricultural areas & 612.43 & $27.71 \%$ & 649.7 & $19.5 \%$ \\
\hline Public services & & & 14.23 & $0.4 \%$ \\
\hline Other land use & & & 27.47 & $0.8 \%$ \\
\hline Energy & & & 64.38 & $1.9 \%$ \\
\hline Total land use (ha) & 2210.08 & & 3327.84 & \\
\hline Population (person) & 77956 & & 154359 & \\
\hline Density (person / ha) & 35 & & 46 & \\
\hline per capita area $\left(\mathrm{m}^{2}\right)$ & 284 & & 216 & \\
\hline $\begin{array}{c}\text { Annual population } \\
\text { growth }\end{array}$ & \multicolumn{3}{|c|}{$3.47 \%$} & \\
\hline Annual area growth & \multicolumn{3}{|c|}{$2.07 \%$} & \\
\hline
\end{tabular}

Diyala Governorate, Directorate of Physical Planning (2013) "Al Muqdadiya City Development

Strategy and Update the Master Plan” Report of Phase 5, p. 8, 35 and 84.

\section{6) Balad City}

It located in Salah ad din governorate, north of Baghdad. It has large green agricultural areas within and around the city, and society is characterized by tribal traditions (Figure 6).

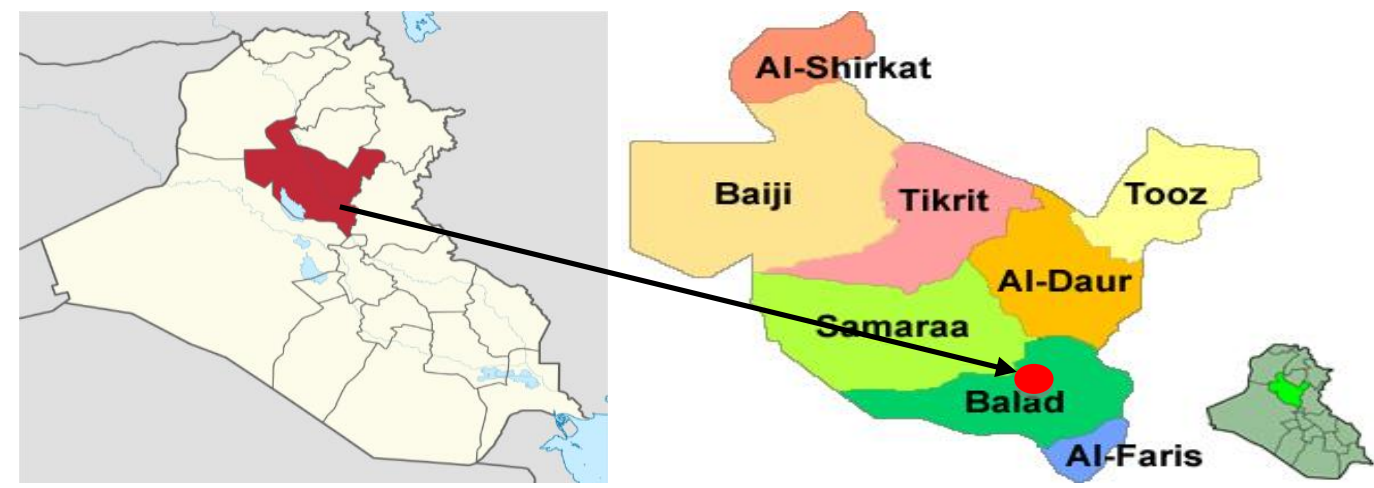

Fig. 6. Location of Salah ad din governorate and Balad city in Iraq

Table (6) shows the

- The city is characterized by the fact that the annual growth of the population and the area is different, as the growth of the population increase by $3.13 \%$ per annum While the growth of the area is very low by $-0.16 \%$ annually. This is a sustainable indicator of the preservation of the land surrounding the city. However, bear in mind that this could not be considered as a city expanding in terms of horizontally and the preservation of the city's boundaries.

- The percentage of built-up areas in the city increased from $31.8 \%$ in 2009 to $57.3 \%$ in 2035, a difference of 25.5 $\%$. While the open spaces ues (green and water) decreased from $66.3 \%$ in 2009 to $31 \%$ in 2035, a difference of $35.3 \%$. This indicates a significant exhaustion of agricultural areas and open spaces within the city's borders. In addition, it has changed the morphology of the city from a green city to built-up city and reducing the level of wellbeing and recreation of the population.

- Increased residential use from $21.1 \%$ in 2009 to $50.3 \%$ in 2035, to accommodate the future population of the city because it is of tribal character and the size of the family is high.

- Increased industrial and production use from $1.2 \%$ in 2009 to $3.6 \%$ in 2035 to increase support for industries related to agriculture such as food industries.

- The land use plan for Balad city (2035) focused on making the city a major economic and administrative center in the region, allocating $11.7 \%$ for mixed uses to give it importance as a future growth pole in the governorate.

- The percentage of agricultural areas decreased from $58.4 \%$ in 2009 to $15.9 \%$ in 2035 . This is an unsustainable indicator in transforming agricultural areas into built-up areas. 


\section{VNJIS Wasit Journal}

VOLUME: ( 7 ), NO.: ( 3 ) 르미므

Balad is a green city that includes many orchards and agricultural areas within the city's boundaries. The city's plan (2035) has suggested increasing the built-up area to accommodate the future expansion of the population by exhaustion the green land in the city instead of preserving it.

TABLE 5. LAND USE OF AL BALAD CiTY FOR 2009 AND 2035.

\begin{tabular}{|c|c|c|c|c|}
\hline \multirow{2}{*}{ Land Use } & \multicolumn{2}{|c|}{2009} & \multicolumn{2}{|c|}{2035} \\
\hline & Area (ha) & Percentage & Area (ha) & Percentage \\
\hline Residential & 446.3 & $21.1 \%$ & 1019.8 & $50.3 \%$ \\
\hline Mixed use & 0 & 0 & 236.2 & $11.7 \%$ \\
\hline Public Services & 37.7 & $1.8 \%$ & & \\
\hline Recreational & 5 & $0.2 \%$ & 25.7 & $1.3 \%$ \\
\hline Public places & 190.9 & $9 \%$ & 15.4 & $0.8 \%$ \\
\hline Transport infrastructures & 1 & $0 \%$ & 14.6 & $0.7 \%$ \\
\hline Technical infrastructures & 5.6 & $0.3 \%$ & 12.4 & $0.6 \%$ \\
\hline Industrial and production & 24.3 & $1.2 \%$ & 72.5 & $3.6 \%$ \\
\hline Agricultural area & 1235 & $58.4 \%$ & 323.1 & $15.9 \%$ \\
\hline Parks, Lakes and landscape & 148.3 & $7 \%$ & 44.7 & $2.2 \%$ \\
\hline Water areas & 18.9 & $0.9 \%$ & 52.8 & $2.6 \%$ \\
\hline Gardens and Orchards & & & 208.7 & $10.3 \%$ \\
\hline Total land use (ha) & 2113 & & 2025.9 & \\
\hline Population (person) & 55200 & & 122957 & \\
\hline Density (person / ha) & 26 & & 61 & \\
\hline per capita area $\left(\mathrm{m}^{2}\right)$ & 383 & & 165 & \\
\hline Annual population growth & & $3.13 \%$ & & \\
\hline Annual area growth & & $-0.16 \%$ & & \\
\hline
\end{tabular}

\section{7) Karbala City}

It is the center of the Karbala governate, located in the Middle of Iraq, one of the most important holy cities in Iraq, a city that attracts high religious tourism and has agricultural potential, orchards and industrial (Figure 7).

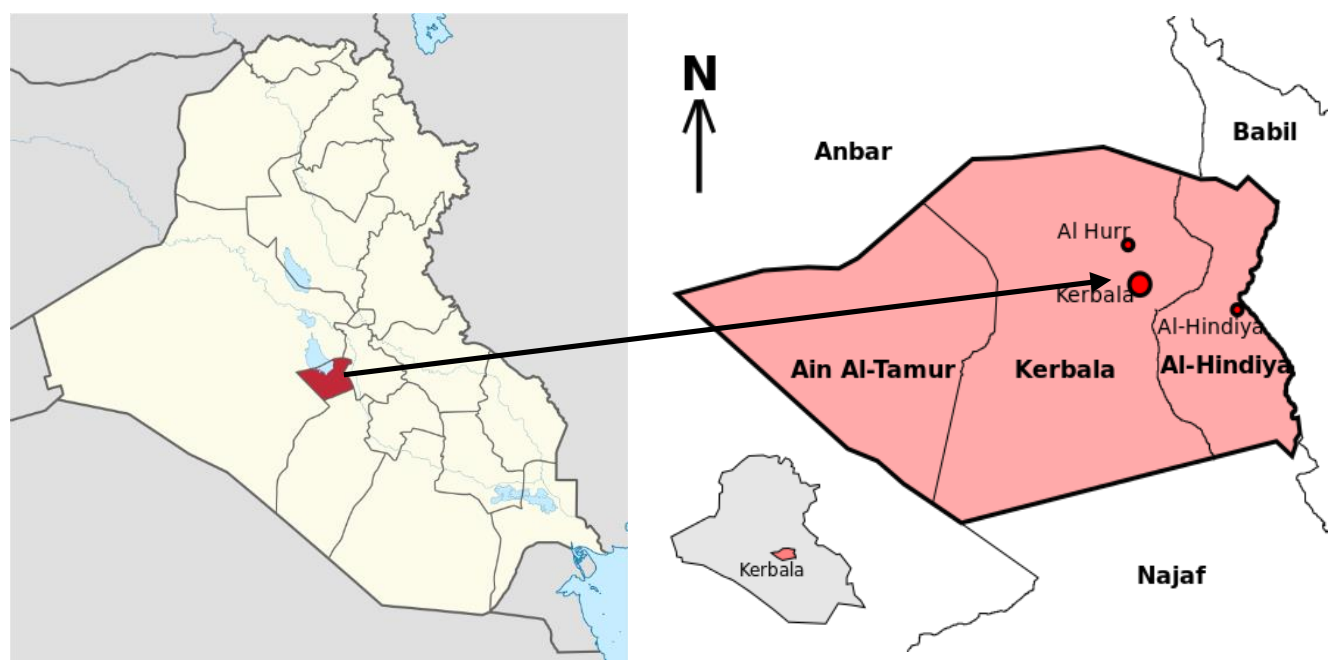

Fig. 7. Location of Karbala governorate and Karbala city in Iraq 
- The annual growth of the population is very high at $3.99 \%$ as a result of the security stability in the city. This encourages emigration from other Iraqi cities and the annual growth of the area by $2.08 \%$. Thus, this indicates the consumption of vacant land and surrounding land in the city, especially agricultural.

- Increased percentage of land use of the following:

- Residential use: The percentage increased from $40.5 \%$ to $48.38 \%$ due to expectations of increased migration to the city. The reason for that is the security stability and holy city that attracts people.

- Industrial use: The percentage increased from $2.2 \%$ to $12.08 \%$ to accommodate the current unemployment and future employment, as well as to exploit the large natural potential available in the governorate.

- Commercial use: The percentage increased from $0.9 \%$ to $3.37 \%$ to accommodate the need of the city and the increase in visitors from outside the city to the holy shrines.

- Warehouses: The percentage increased from $1.6 \%$ to $8.66 \%$ because the city is a center for producing and exporting dates out of Iraq, therefore, it needs to provide large stores to collect dates from all over Iraq.

- Transportation: The percentage increased from $1.5 \%$ to $4.8 \%$ to accommodate the urban expansion of the city and to preserve the city's compactness, as the city has a compact traditional layout.

- Decreased percentage of the following land uses, which represents uses that could support sustainability in the city:

- Public Services: The percentage decreased from $7.3 \%$ to $3.33 \%$. This leads to a decrease in the level of wellbeing and the provision of a healthy, educational and service environment for the community.

- Open space and green and agricultural areas: The percentage decreased from $36.6 \%$ to $19.39 \%$ as a result of the horizontal expansion of the city and its exhaustion by other land uses. This is an unsustainable indicator that has the negative effects on the city from the environmental, health and psychological aspects of the community.

Karbala is the most important holy religious city in Iraq, its religious and high population attractions, with a compact urban fabric. It surrounded by many orchards and agricultural areas. The plan (2030) of the land uses focused on making the city a strong multi-source economy (tourism, industry, trade) and making the city a major growth pole in Iraq because of its religious significance. The plan (2030) focusing on the consumption of the agricultural area surrounding the city and its transformation for residential and economic uses.

TABLE 7. LAND USE OF KARBALA CITY FOR 2007 AND 2030

\begin{tabular}{|c|c|c|c|c|}
\hline \multirow{2}{*}{ Land Use } & \multicolumn{2}{|c|}{2007} & \multicolumn{2}{|c|}{2030} \\
\hline & Area (ha) & Percentage & Area (ha) & Percentage \\
\hline $\begin{array}{l}\text { Residential (including streets } \\
\text { in neighborhoods and green } \\
\text { squares) }\end{array}$ & 4374.64 & $40.5 \%$ & 8381 & $48.38 \%$ \\
\hline Industrial & 230.44 & $2.2 \%$ & 2092 & $12.08 \%$ \\
\hline Commercial & 95.86 & $0.9 \%$ & 583 & $3.37 \%$ \\
\hline Warehouse & 175 & $1.6 \%$ & 1500 & $8.66 \%$ \\
\hline Educational & 256.82 & $2.4 \%$ & \multirow{4}{*}{$\begin{array}{l}576 \text { (Public } \\
\text { services) }\end{array}$} & \multirow{4}{*}{$3.33 \%$} \\
\hline Health & 29.56 & $0.3 \%$ & & \\
\hline Religious & 14.36 & $0.1 \%$ & & \\
\hline Cemeteries & 484.3 & $4.5 \%$ & & \\
\hline $\begin{array}{l}\text { Public facility (green and } \\
\text { parking) }\end{array}$ & 901.37 & $8.4 \%$ & 1391 & $8.03 \%$ \\
\hline Transport and roads & 165.59 & $1.5 \%$ & 832 & $4.8 \%$ \\
\hline Agricultural area & 3044.98 & $28.2 \%$ & 1967 & $11.36 \%$ \\
\hline Vacant area & 1018.23 & $9.4 \%$ & 0 & 0 \\
\hline Total land use (ha) & 10791.13 & & 17322 & \\
\hline Population (person) & 603675 & & 1483684 & \\
\hline Density (person / ha) & 56 & & 86 & \\
\hline per capita area $\left(\mathbf{m}^{2}\right)$ & 179 & & 117 & \\
\hline Annual population growth & \multicolumn{3}{|c|}{$3.99 \%$} & \\
\hline Annual area growth & \multicolumn{3}{|c|}{$2.08 \%$} & \\
\hline
\end{tabular}

Ministry of Municipalities and Public Works, General Directorate of Physical Planning (2007) "Karbala

Master Plan Upgrade" Setting and Evaluating Alternatives Stage Report, p. 2-5 and 5-26. 
V. CONCLUSION

1) The cities of Karbala, Ramadi, Al Muqdadiya and Balad are attractive to the population due to various reasons including security stability and the existence of economic potential such as agriculture. The lowest annual population growth is in the city of Amarah because of the exodus of residents as a result of population migration to other governorates looking for jobs.

2) We note that the city of Balad maintained the boundaries of the master plan of the city and not expand beyond its borders. While the rest of the cities have expanded the pattern of urban sprawl, that have multiple negative effects.

3) The population density of most Iraqi cities is low when compared with the sustainable densities (150 people/ha) as a result of relying on the horizontal housing pattern and not expanding vertically pattern, therefore, it is noted that the percentage of residential use in Iraqi cities is between $21-56 \%$ of the total area of the city.

4) The percentage of industrial use in Iraqi cities is between 1-12\% of the total area of the city. Most of them were based on heavy and medium industries and did not rely on light industries.

5) The highest percentage of commercial and mixed use is $12 \%$. Most of the master plans of Iraqi cities lack of mixed use, which is a tool for sustainability.

6) The percentage of green, agricultural and recreational areas in the existing of Iraqi cities is between 1-66 \%, while the future percentage is between 11-32\%. This indicates that there is consumption of these lands This provides a viable environment and achieve sustainability for the uses of the land.

7) The percentage of roads and transportation in Iraqi cities is up to $25 \%$. This percentage encourages the use of private cars. The reason for that is the land use plans in Iraqi cities don't focus on sustainable transportation in order to encourage the community to use means of sustainable transportation.

\section{REFERENCES}

1. Diyala Governorate, Directorate of Physical Planning (2013) "Al Muqdadiya City Development Strategy and Update the Master Plan" Report of Phase 5.

2. Frenkel, Amnon (2004) "The Potential Effect of National Growth Management Policy on Urban Sprawl and the Depletion of Open Spaces and Farmland" Elsevier Ltd, Land Use Policy, Volume 21, Issue 4, p. 357-369.

3. Halcrow Group Limited (2007) "The Asian Development Bank- Study on Sustainable Urbanization in Metropolitan Regions" Tsinghua University, PRC and the UCL Development Planning Unit, UK.

4. Li, Xia \& Yeh Anthony (2000) "Modelling Sustainable Urban Development by the Integration of Constrained Cellular Automata and GIS" Taylor \& Francis Ltd, International Journal of Geographical Information Science, vol. 14, no. 2.

5. Marceau, Danielle J. \& Wang, Fang \& Wijesekara, Nishad (2013) "Investigating Land-Use Dynamics at the Periphery of a Fast-Growing City with Cellular Automata at Two Spatial Scales" Springer-Verlag Berlin Heidelberg.

6. Ministry of Municipalities and Public Works, General Directorate of Physical Planning (2012) "Basra City Development Strategy and Update the Master Plan" Report of the sixth phase, chapter III, p. 8, chapter IV p. 1, and chapter VI.

7. Ministry of Municipalities and Public Works, General Directorate of Physical Planning (2009) “Amara Master Plan Update" Population and demographic characteristics Report.

8. Ministry of Municipalities and Public Works, General Directorate of Physical Planning (2012) "Ramadi City Development Strategy and Update the Master Plan" Report of Phase V, Final Outline of the Master Plan.

9. Ministry of Municipalities and Public Works, General Directorate of Physical Planning (2009) "Hillah Master Plan Update" Report of Phase VI, Chapter III.

10. Ministry of Municipalities and Public Works, General Directorate of Physical Planning (2007) "Balad Master Plan Update" Report phase IV, chapter II, p. 26, chapter IV.

11. Ministry of Municipalities and Public Works, General Directorate of Physical Planning (2007) "Karbala Master Plan Upgrade" Setting and Evaluating Alternatives Stage Report.

12. Osaragi, Toshihiro \& Nishimatsu, Teruo (2013) "A Model of Land Use Change in City Areas Based on the Conversion of Unit Lots" Springer-Verlag Berlin Heidelberg.

13. Paola Sassi (2006) "Strategies for Sustainable Architecture" Taylor \& Francis. 
14. UN-Habitat (2014) "A New Strategy of Sustainable Neighborhood Planning: Five Principles" Urban Planning Discussion Note 3.

15. Wagle, Gaurish (2014) “Masdar City: Planning a Sustainable, Smart City - An Integrated Approach" $12^{\text {th }}$ International Conference on emerging trends in Sustainable Habitat and Integrated Cities. 